\title{
Landmark Halifax decision heads to appeal court
}

$\mathrm{D}$ r. Gabrielle Horne broke new legal ground this summer when a jury awarded the Halifax cardiologist \$1.4 million in damages the highest amount ever handed down in Canadian history for loss of reputation and career. The celebration, however, has proven short-lived. Horne has now appealed the court decision and the Nova Scotia Health Authority has filed a cross appeal.

Horne, who was also awarded more than $\$ 550000$ in legal-related costs, says she had no choice but to return to court given that the Nova Scotia Health Authority (NSHA) has not paid or communicated with her since the decision. "It's a very difficult situation. The hospital refuses to acknowledge the finding of the jury and that they acted in bad faith or malice," she says.

Horne and her lawyer are asking the Nova Scotia Court of Appeal to ascertain whether Horne has an employment contract with the health authority. If the appeal court agrees this is the case (the Nova Scotia Supreme Court previously said there was no contract), it could increase the amount of damages awarded. "If there is a breach of contract, then Dr. Horne can advance a different argument," says Michael Wright, her lawyer.

For its part, the Nova Scotia Health Authority contends it wants what Horne wants: to put this behind them. "NSHA shares what we understand to be Dr. Horne's position — specifically, that it is desirable to put this matter to rest," says spokesperson Kristen Lipscombe.

However, she adds, the health authority could not let the landmark decision go unchallenged. "The jury awarded $\$ 1.4$ million. That award is significantly higher than any similar award made by any other court in

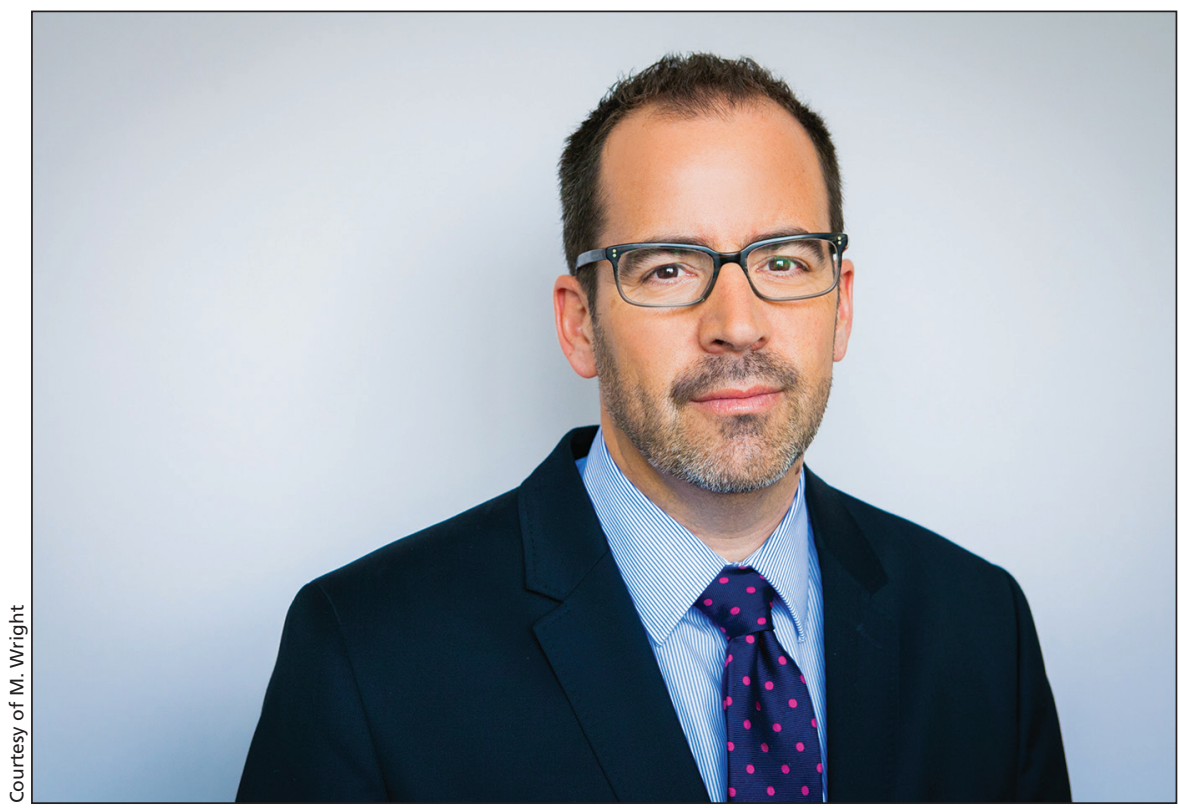

Lawyer Michael Wright says Dr. Gabrielle Horne is seeking to re-establish her track record.

Canada. One of the roles of our appeal system is for the court of appeal to review jury verdicts to ensure they are reasonable in light of the current law of the province and the country."

The legal saga began in 2002 when Horne refused to include a senior physician in her research team or as an author on publications on research into heart failure. Her privileges were suspended amid accusations that she endangered patients, conducted unethical research and failed to be collegial.

In a civil trial this spring, the jury determined that Horne's loss of privileges constituted bad faith or malice. Numerous issues were identified. The Nova Scotia government, for example, has bylaws in place to ensure that when a physician's privileges are suddenly varied, the review process takes no more than two weeks. For Horne, that process took four years.
When the then Capital Health board of directors suddenly reinstated the cardiologist's privileges in 2006, it said their decision turned solely on a procedural issue. "The hospital wouldn't take any responsibility for what had happened. I was publicly smeared and still reporting to the same individuals," says Horne. "I really didn't have any choice but to pursue legal action."

Now, with these appeals, the legal saga continues and Horne will likely lose at least another year she could be devoting to research on genetic disorders that affect the connective tissue of arteries and other body systems.

"We were seeking at trial essentially funding for her to commence her research and to re-establish her track record," says Wright. - donalee Moulton, Halifax, NS

CMAJ 2016. DOI:10.1503/cmaj.109-5344 